she was struck at the lower part of the abdomen by the footstep of a cart, and thrown on her right hip, the vehicle passing obliquely over her (though this last is not quite clear.) She appears first to have been treated by a bone-setter, who did not discover the fractured pelvis, and after trying ineffes. tually and at different times various mechanical appliances and remedies, ended by putting a dozen leeches on. After the accident she had incontinence of urine, and was confined to her bed eight months, unable during all that time to stand, nor can she now perfectly for long, or walk any distance; she always limps, and had partial paralysis of both lower extremities for some time afterwards, and has since suffered frequent shooting pains in her hip and across the pelvis. The right leg is three quarters of an inch shorter than the left, which has been œdematous ever since. Subsequently she applied to a qualified surgeon, but then it was too late. She had four children prior to the accident, but none after till this confinement. Her age is thirty-seven, and height about five feet three inches.

Brighton, January, 1856.

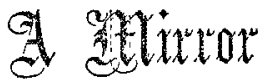

OF THE PRACTICE OF

\section{MEDICINE AND SURGERY IN THE}

\section{MOSPITALS OF LONDON.}

Nulla est alia pro certo noscendi via, nisi çuam plurimas et morborum etdissectionum historias, tam aliorum proprias, collectas habere et inter secomparare.-Morgagni. De Sed. et Caus. Drorb. Lib. It. Procemium.

\section{ST. THOMAS'S HOSPITAL.}

COMPOUND CORMINUTED FRACTURE OF THE RIGHT LEA, WTPH BAD FRACTURE OF THE LEFT LEG AISO; DOUBLE AMPUTATION; SECONDARY HEIIORREAGE; RECOVERY.

(Under the care of Mr. Le Gros Clank.)

There have of late been in the hospitais a great many of those severe cases of fracture-the dreadful consequences of railway collisions, and best described by the emphatic word, smash-that immediately call for amputation. The frequent occurrence of these accidents creates in the surgeon of this generation a more lively interest than was, perhaps, in any previous age felt by the practitioner, in the advantages and disadvantages held forth by the different modes and varieties of operation, and the probable results, under different circunastances, of primary and secondary amputations. The statistics which the latest works on surgery give us of the great mortality following amputations for disease, and the great proportion of deaths after secondary, and the yet more alarming results from primary, operations for injury, may well cause the surgeon doubt and anxiety in deciding on the course to be pursued in cases of severe fracture. The tables published by Mr. Erichsen, in his volume on "Surgery," show that in amputations of the thigh, in University College Hospital, after disease, the mortality is $20 \frac{1}{2}$ per cent., and in operations after injury 58 per cent. Malgaigne's statistics are yet more terrible. In the Parisian hospitals it would appear that, in amputations of the thigh after disease, the deaths are as many as 60 per cent., and after injury not less than 75 per cent. "The shock," says Mr. Erichsen, "inflicted by injury appears to be one of the principal reasons of the greater frequency of the mortality after operations for injury than of those for disease. After amputations also there is a greater liability to the occurrence of gangrene of the stump, and pyæmia and its secondary effects, than in the case of the removal of a limb for disease, in which the principal causes of death usually appear to be exhaustion and the supervention of disease of the lungs."

On turning from the mortality of the amputations for injury and for disease, and on proceeding to consider the respective results of primary and secondary operations, we are met by facts worthy of note, and difficult to be accounted for. Of forty-four cases of primary amputation of the thigh recorded by Malgaigne, thirty-four perished; and of thirty-four cases recorded by South, Laurie, and Peacock, as occurring in St. Thomas's Hospital, at the Glasgow Infirmary, and the Edinburgh Infirmary, every one proved fatal; and we have been informed on good authority that all the primary operations lately performed in the Crimea have been followed by death. From this, the deadly character of the primary operation appears to be such that a cautious surgeon might well fear to have recourse to it; yet, in University College Hospital, out of six cases of primary amputations of the thigh, three were cured, and three died; and in thirteen cases of secondary operation, five were cured, and eight died, - showing a mortality for the primary operation of 50 per cent., and for the secondary of 61 per cent. Of course, the results of six cases are not enough to overthrow the testimony of the sixty-eight cases furnished by Malgaigne, South, Laurie, and Peacock, still they cannot be without influence on the minds of reflective observers.

The history of the case under Mr. Le Gros Clark is as follows :-

Thomas F. A—, aged forty-five, a healthy man, by trade a confectioner, was brought into the hospital on the Fth of December, having, with many others, suffered from the smash of a railway-carriage. There was found to be compound comminuted fracture of the right leg, with comminuted fracture of the left leg also. On coning to himself next day, he gave us his reminiscences of the accident, saying that he was sitting in a carriage that was proceeding with great velocity, when the crash came suddenly, and the seat he occupied shot forth against the opposite one, so that his legs were shattered, and cut behind and before, as if in a gigantic pair of shears. On putting his hand immediately to the injured parts, he picked out some pieces of bone which fell about the carriage, when faintness seized him, and he became insensible. He had no further remembrance, either of the catastrophe or of the operations he subsequently underwent under the influence of chloroform. At eleven o'clock of the same evening, Mr. Clark remored the right leg, high up; and at about the same hour the next morning (after an interval of twelve hours), amputation of the left limb was performed by the same surgeon. On being first admitted into the hospital, the pationt was given twenty drops of Battley's solution, which apparently had a satisfactory effect on him; but it was afterwards found he did not bear opiates well. Six ounces of wine were prescribed for him. On the 8 th, and on the 9 th, he was ordered beef-tea and other means of generous support.

Dec. 12th. - Patient going on satisfactorily. He has been ordered the quinine mixture of the hospital, and a dose of morphia at night. He derives great comfort from one of Hooper's air-pillows. His pulse and appearance are good.

14th.--Patient still croing on well, but is much exhausted. Jelly, wine, and ammonia have been liberally administered during the last two days.

Nothing of interest occurred in the case for the next fortnight, except an attack of secondary hæmorrhage, which at one time was alarming, but submitted to ordinary remedial measures.

28th.-Patient going on favourably, except that the fetor from the stumps has been excessive.

Jan. 5th, 1856. - The progress of the patient continues to be most satisfactory. His spirits are excellent, his pulse is full and soft, and his appetite is good. The ligatures have all come away, and the stumps look healthy.

14th. - The patient is going on rapidly and well. It is, however, to be observed, that the stump of the limb that was removed on the evening of the accident has done much better, and is in a far more favourable condition, than the stump of the other leg that was amputated at eleven o'clock the next morning.

\section{ST. MARY'S HOSPITAL}

AMTPUTATION FOR DEFORMITY AND OLD-STANDING DISEASE OF TIIE KNET-JOINT.

(Under the care of Mr. CouLson.)

LCcy $\mathrm{B}-$, aged thirty-eight, the wife of a shoemaker, was admitted into St. Mary's Hospital on November 17th, 1855, for an affection which commenced as far back as sixteen years. Her health has generally been good, and she has had a family of five children. There was notbing in her appearance indicating any serious organic disease. Sixteen years ago she first experienced an uneasy sensation in the left knee. The painful part soon became swollen; the enlargement affected in an uniform manner the joint, which was cupped, leeched, and other. wise treated, soon after which she became an in-patient of, an 